\title{
Gut-brain Axis and migraine headache: a comprehensive review
}

\author{
Mahsa Arzani ${ }^{1 \dagger}$, Soodeh Razeghi Jahromi ${ }^{2 \dagger}$, Zeinab Ghorbani ${ }^{3+}$, Fahimeh Vahabizad ${ }^{1,4}$, Paolo Martelletti ${ }^{5}$, \\ Amir Ghaemi ${ }^{6}$, Simona Sacco ${ }^{7 *}$, Mansoureh Togha ${ }^{1,4^{*}}$ (D) and On behalf of the School of Advanced Studies of the \\ European Headache Federation (EHF-SAS)
}

\begin{abstract}
The terminology "gut-brain axis "points out a bidirectional relationship between the Gl system and the central nervous system (CNS). To date, several researches have shown that migraine is associated with some gastrointestinal (Gl) disorders such as Helicobacter pylori (HP) infection, irritable bowel syndrome (IBS), and celiac disease (CD). The present review article aims to discuss the direct and indirect evidence suggesting relationships between migraine and the gut-brain axis. However, the mechanisms explaining how the gut and the brain may interact in patients with migraine are not entirely clear. Studies suggest that this interaction seems to be influenced by multiple factors such as inflammatory mediators (IL-1 $\beta, I L-6, I L-8$, and TNF-a), gut microbiota profile, neuropeptides and serotonin pathway, stress hormones and nutritional substances. Neuropeptides including CGRP, SP, VIP, NPY are thought to have antimicrobial impact on a variety of the gut bacterial strains and thus speculated to be involved in the bidirectional relationship between the gut and the brain. According to the current knowledge, migraine headache in patients harboring HP might be improved following the bacteria eradication. Migraineurs with long headache history and high headache frequency have a higher chance of being diagnosed with IBS. IBS and migraine share some similarities and can alter gut microflora composition and thereby may affect the gut-brain axis and inflammatory status. Migraine has been also associated with CD and the condition should be searched particularly in patients with migraine with occipital and parieto-occipital calcification at brain neuroimaging. In those patients, gluten-free diet can also be effective in reducing migraine frequency. It has also been proposed that migraine may be improved by dietary approaches with beneficial effects on gut microbiota and gut-brain axis including appropriate consumption of fiber per day, adhering to a low glycemic index diet, supplementation with vitamin D, omega-3 and probiotics as well as weight loss dietary plans for overweight and obese patients.
\end{abstract}

\section{Introduction}

Based on global burden of headache reports in 2016, it was estimated that approximately $14 \%$ of the adult population worldwide suffer from migraine [1]. The disease is three times more prevalent among females and imposes high burden at the individual and society level. According

\footnotetext{
* Correspondence: simona.sacco@univaq.it; togha1961@gmail.com Dr. Razeghi Jahromi, Dr. Arzani and Dr. Ghorbani have equally taken part as first authors

${ }^{\dagger}$ Mahsa Arzani, Soodeh Razeghi Jahromi and Zeinab Ghorbani contributed equally to this work.

${ }^{7}$ Neuroscience section - Department of Applied Clinical Sciences and Biotechnology, University of L'Aquila, L'Aquila, Italy

${ }^{1}$ Headache Department, Iranian Center of Neurological Research,

Neuroscience Institute, Tehran University of Medical Sciences, Tehran, Iran Full list of author information is available at the end of the article
}

to Global Burden of Disease (GBD) study 2018, migraine has been recognized as the first leading cause of disability in those aged less than 50 years $[2,3]$. The exact pathogenesis of migraine is still undefined but implies numerous factors, including the gut-brain axis [4].

The terminology "gut-brain axis "points out a bidirectional relationship between the GI system and the central nervous system (CNS). Brain normally regulates movements and functions of the GI tract (sensory and secretion). Hormonal factors through the hypothalamic pituitary adrenal (HPA) axis by mediating stress responses impact on the gut functions. On the other hand, GI system is believed to be able to affect the CNS. A number of the brain functions such as cognition, behavior and even nociception are 
under the influence of the gut system [5, 6]. The dysfunction of the gut-brain axis has been implicated in a number of neurological disorders such as multiple sclerosis, mood and anxiety disorders, Alzheimer disease, Parkinson disease, and migraine $[5,6]$. Figure 1 depicts the mechanisms of the bidirectional relationship between the gut and the brain in migraine (Fig. 1). Several neurotransmitters have been supposed to play a role in this process including serotonin, dopamine, gamma-aminobutyric acid, and calcitonin generelated peptide (CGRP) [6-8].

The present review article aims to discuss the direct and indirect evidence suggesting relationships between migraine and the gut-brain axis. As it will be clarified later, this interrelationship seems to be influenced by multiple factors such as inflammatory mediators, gut microbiota profile, neuropeptides, stress hormones and nutritional substances. In this regard, at first we will take a look at the involvement of inflammation in migraine headache and role of gut microbiome. Afterwards, the role of the neuropeptides specifically serotonin pathway in relation to migraine and gut-brain axis will be explored. Later, the current evidence on the association between migraine and gastrointestinal (GI) disorders including Helicobacter pylori (HP) infection, irritable bowel syndrome (IBS), celiac disease (CD) and inflammatory bowel disease (IBD) will be described. Finally, the effects of probiotic supplementation on migraine and possibly effective dietary approaches for migraine patients including modifying carbohydrate and fat intake, vitamin supplementation and weight loss diets will be discussed.

\section{The involvement of inflammation in migraine headache and role of gut microbiome}

In the gut, immune cells and their inflammatory mediators such as interleukin (IL)-1 $\beta$, IL-6 and IL-18, tumor necrosis factor alpha (TNF- ), and interferon gamma (IFN)have been implicated as sensitizers of afferent endings and are known as inducers of visceral pain $[9,10]$. Additionally, proinflammatory cytokines, including IL-1 $\beta$, IL-6, IL-8, and TNF- $\alpha$ have been implicated in migraine pain and are increased during migraine attacks $[11,12]$.

Most of the studies aiming to investigate the roles of gut microflora in different disorders, usually use microbiota deprivation or "germ-free" murine models. These animals are grown in a sterile condition and therefore are microbiota-deficient [13]. In this regard, the importance of the immune system in the gut-brain axis and in migraine pathobiology is also supported by the evidence that hypernociception caused by inflammatory stimuli can decrease in germ-free compared to conventional mice [14]. This result highlights the important role played by gut microbiota in preparing the host adaptation to stress factors in the environment, which induce pain [14].

It is noteworthy that the composition of the gut microbiota plays a major role in gut-brain axis. This happens via two mechanisms: indirect signaling, including microbiotaderived neurotransmitters, inflammatory molecules, and hormones; and direct connection with stimulating end terminals of the vagus nerve (Fig. 2). Also in this case, the mechanism is bidirectional as CNS can modulate gut microbiota throughout sympathetic and parasympathetic systems and by releasing neuroendocrine peptides [15]. Changes in the intestinal microbiota profile may occur as a result of psychological and physical stress factors. These stressors stimulate release of corticotrophin-releasing hormone in hypothalamus, that induces cortisol secretion from the adrenal glands, and may lead to alterations in the permeability of the intestines through changing the microbiota profile. Finally these events could lead to dysbiosis

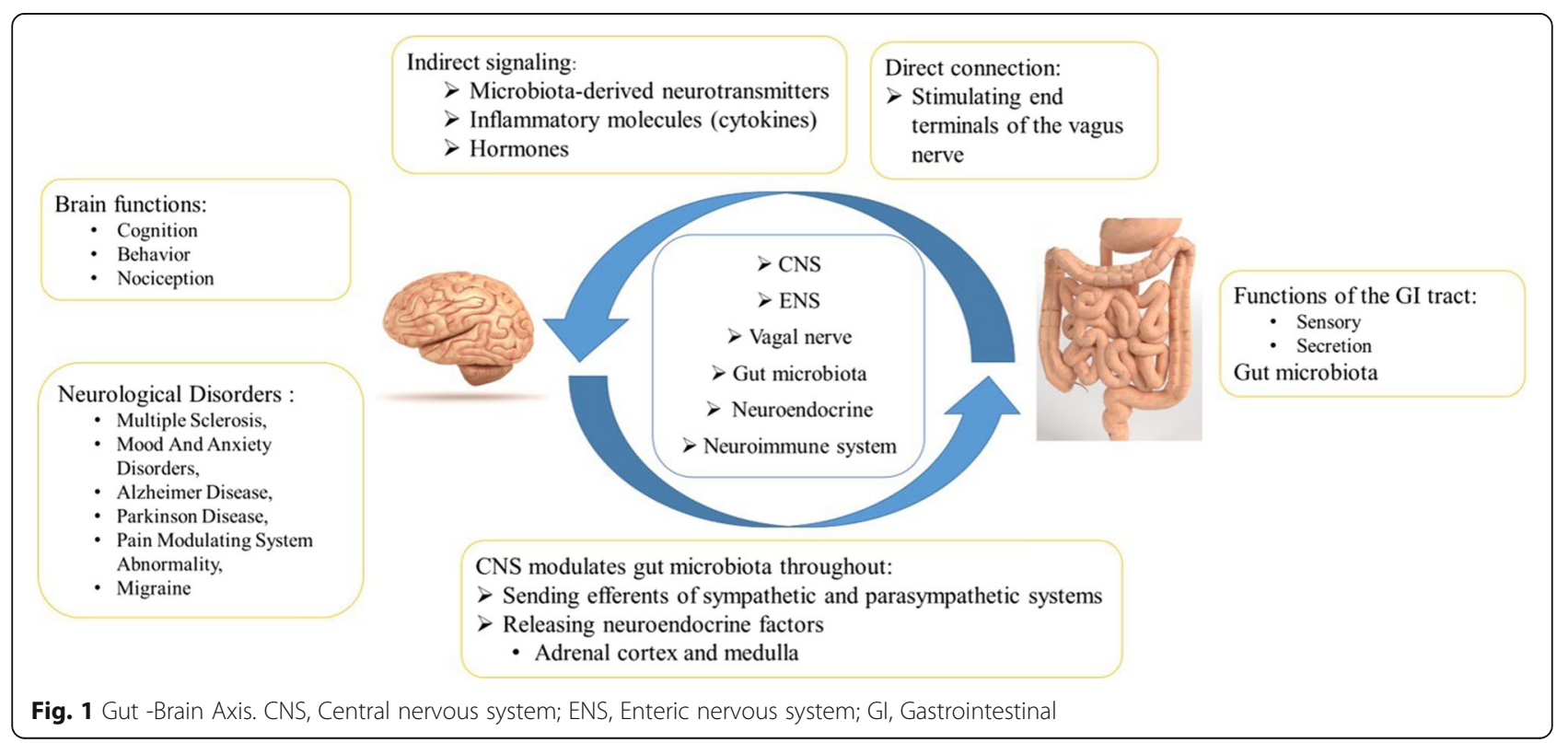




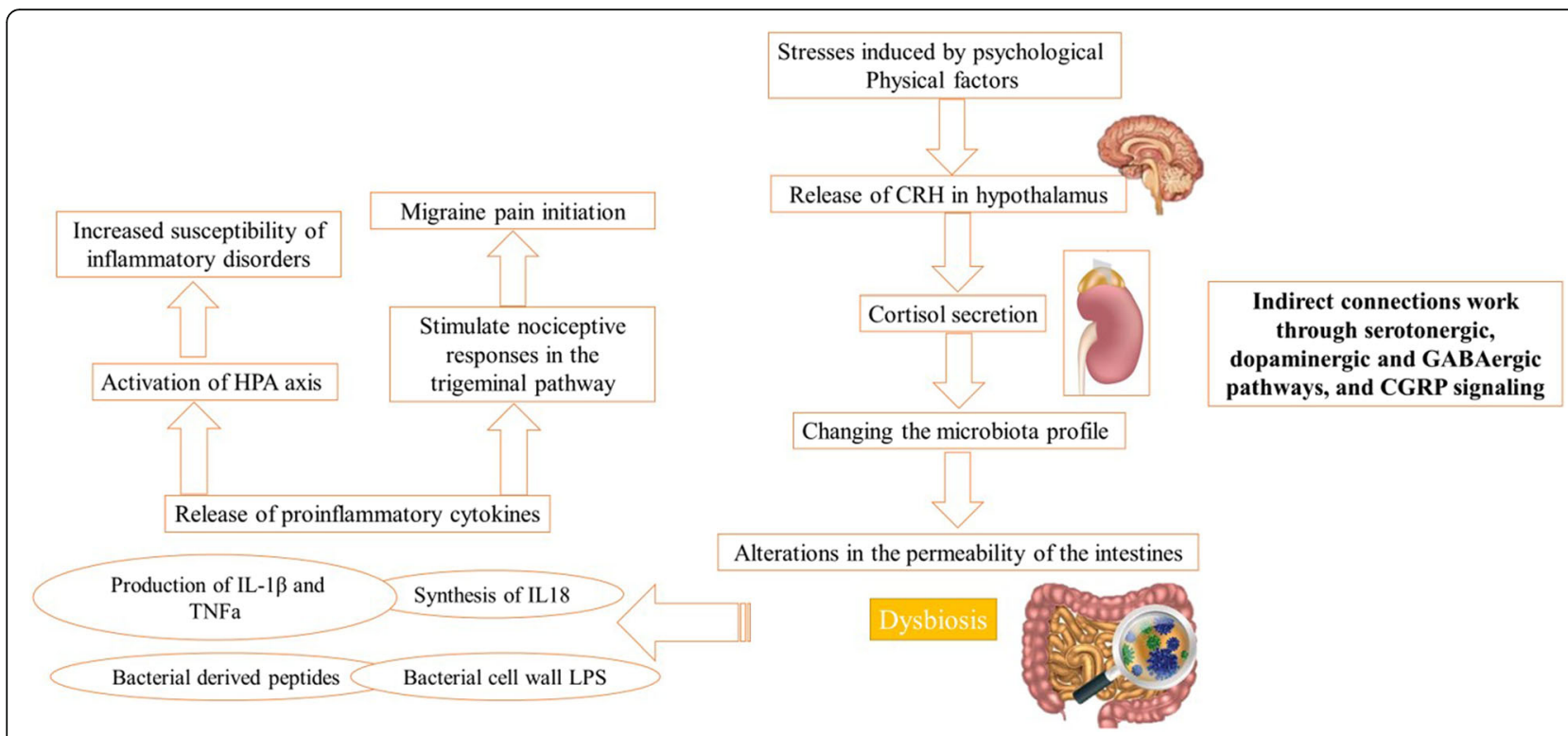

Fig. 2 Mechanisms of the effects of gut bacteria in keeping normal balance of gut-brain axis via indirect signaling. CGRP, Calcitonin gene-related peptide; $\mathrm{CRH}$, Corticotrophin-releasing hormone; HPA, Hypothalamic pituitary adrenal axis; LPS, lipopolysaccharides; IL, Interleukin; TNFa, Tumor necrosis factor alpha

(changes in microbiota profile of the gut) [6, 16-19]. On the other hand, dysbiosis of GI microbiota and increased gut permeability may lead to activation of HPA axis through the release of proinflammatory cytokines such as IL- $1 \beta$ and TNF- . The release of cytokines may be inhibited by the stress-induced steroid response which anyhow increases the susceptibility of inflammatory disorders [20-23].

Substances such as CGRP, substance P (SP), vasoactive intestinal peptide (VIP), and neuropeptide Y (NPY), are thought to have antimicrobial impact on a variety of the gut bacterial strains (for instance Escherichia coli, Enterococcus faecalis, and Lactobacillus acidophilus) and thus speculated to be involved in the bidirectional relationship between the gut and the brain [15]. It has also been reported that the colonic concentration of SP increases in response to antibiotic treatment and subsequent dysbiosis while Lactobacillus paracasei administration attenuated this response [24]. Studies of peripherally administrated CGRP in animal models demonstrated CGRP inhibits basal and stimulated gastric acid secretion [25, 26]. In addition, CGRP is a potent inhibitor of pancreatic enzyme secretion via modulation of a central vagal out flow [27]. On the other hand, as CGRP signaling could be influenced by microbiota [15].

Nutritional factors may influence the mechanisms through which the gut microbiota manages gut health and immune function [28]. Short-chain fatty acids (SCFAs, namely: butyrate, propionate, and acetoacetate) are crucial in maintaining gut barrier integrity. These substances are produced by bacteria in the distal colon [29-32]. It has been suggested that gut microbiota activities and consequently the levels of SCFAs in the gut might be affected by dietary factors including fiber and probiotics [31]. Apart from affecting gut/systemic immunity, SCFAs bypass portal circulation and could reach the CNS via circulation. In CNS, SCFAs have neuroprotective properties. For instance, sodium butyrate, the salt of butyrate, stimulates cell proliferation and differentiation in the dentate gyrus, and enhances the expression of brain-derived neurotrophic factor (BDNF) and glial-derived neurotrophic factor (GDNF). Butyrate also shows anti-inflammatory effect in the brain by suppressing the synthesis of TNF- $\alpha$, induced by the endotoxin lipopolysaccharides (LPS) through the suppression of nuclear factor $\mathrm{\kappa B}$ [32]. Additionally, changes in SCFAs producing phyla can affect immune function of the host. Rapid and extreme dietary changes directly affect gut microbiota because they influence the beta diversity of the gut microbiota (scale of measuring the turnover of the microbiota species) [33, 34]. Interestingly, adding prebiotics (fermentable fibers) to high-fat diet was reported to restore the decreased levels of butyrateproducing bacteria and Bifidobacteria which also highlights the critical influence of diet on composition of the gut microbiota [35].

Therefore, due to the bidirectional association between permeability of the gut and inflammatory state, augmented gut permeability can stimulate inflammatory and immune responses through LPS leakage and subsequently proinflammatory cytokines can reinforce gut permeability $[36,37]$. On the other hand, as mentioned, proinflammatory cytokines such as TNF- $\alpha$, IL- $1 \beta$ and 
IL-6 could also affect nociceptive responses in the trigeminal pathway and play a role in migraine pain initiation [38-43]. Figure 2 demonstrates the mechanisms of the effects of gut bacteria in keeping normal balance of gut-brain axis via indirect signaling in which these inflammatory cytokines play an important role.

\section{The role of the neuropeptides in migraine headache with a focus on the gut-brain axis}

Glutamate, as an excitatory neurotransmitter, plays a role in migraine pathophysiology through different effects including cortical spreading depression (CSD), central sensitization, and by stimulating trigeminovascular system. Increased glutamate levels in the plasma and CSF of migraineurs in comparison with control subjects have been reported previously $[44,45]$. On the other hand, the role of this neurotransmitter in the enteric nervous system (ENS) and the gut-brain axis (transmitted along afferent neurons from the gut into the brain) has been studied in depth. Also, it was indicated that glutamate might affect the inflammation and oxidative stress in the GI tract [46]. The disturbances in glutamate pathway appeared to be involved in the pathogenesis of a variety of GI disorders such as IBD, IBS, gastroesophageal reflux, gastric acid hyper-secretory disorder [46].

NPY, a probable indicator of noradrenergic system function, affects cerebral blood flow through cerebral circulation regulation. It is worth mentioning that higher levels of NPY has been detected in ictal phases of migraineurs $[15,44]$. Interestingly, this neurotransmitter has been detected at all levels of the gut-brain axis. NPY pathway is also assumed to contribute to changing GI function and its blood flow, immunological system and inflammation status, pain, homeostasis of energy, emotion, mood, as well as behavior and other functions of the brain (e.g. cognition) [15, 44, 47].

One of the main biomarkers of migraine, CGRP, inhibits gastric acid secretion and may suppress food intake [48]. As mentioned, CGRP signaling could be influenced by microbiota as such increased level of this neurotransmitter in dysbiosis might be one of the probable justification for prescribing probiotics in migraine [15].

Cholecystokinin (CCK) is synthesized by enteroendocrine cells in the mucosal lining of small intestine (I cells), mammalian brain (eg. cortex, thalamus, mesolimbic, periaquiductal gray matter (PAG) and midbrain), and spinal cord. This peptide inhibits gastric emptying and acid secretion, stimulates gall bladder contraction and pancreatic secretion, and provokes satiety feeling in the brain via CCK1 receptor. The presence of CCK1R on vagal afferent terminals lying in the wall of GI tract further confirms the hypothesis of endocrine and paracrine collaboration. The location of CCK1R in mesolimbic structures, hypothalamus and brain stem nucleus and its interaction with dopamine, serotonin, glutamate, hypothalamic hormones, and neuropeptides explains specific roles of CCK in behavior, mood, and extrapyramidal function $[49,50]$. Like CGRP, CCK is produced in the PAG and may be responsible for endogenous pain signaling system and its level increases in migraine [51]. CCK is also present in trigeminal ganglion, such that stimulation of trigeminal ganglion results in increasing local CCK [52]. On the other hand, obese patients had a significantly higher frequency and severity of migraine attacks as compared to overweight or normal weight individuals [53]. A meta-analysis study found an increased risk of having migraine in obese subjects; also the risk of chronic migraine is higher in obese subjects than in normal weight group [54]. One of the possible explanations for the association between migraine and obesity is CCK secretion in response to high fat diets as intra-duodenal free fatty acids stimulate CCK secretion [55].

\section{Serotonin pathway involvement in migraine headache with a focus on the gut-brain axis}

It has been proposed that tryptophan-kynurenine pathway might be one of the main ways by which GI microbiota may affect the function of the CNS due to the presence of synthetic enzymes in bacterial strains of the intestine that may produce tryptophan metabolites (such as quinolinic and kynurenic acids) [16, 56]. As tryptophan is the precursor of serotonin, the amount of this neurotransmitter in the brain depends on hthe levels of this amino acid $[16,56]$.

The role of gut microbiota in anxiety, depression and the HPA axis has been studied through assessing the effects of prebiotics and probiotics administration in these conditions [57-59]. It has been reported that "germ-free" mice may have increased plasma levels of serotonin and tryptophan. These reports may justify the role played by hormonal factors in the association between gut bacterial strains and tryptophan levels $[16,56,60]$. Moreover, the turn-over of serotonin as shown by increased levels of the pathway metabolites, has been reported to be elevated in germ-free animals; while it has been demonstrated that supplementation with probiotic lead to lessen the concentration of 5-hydroxyindoleacetic acid (5-HIAA) and kynurenine in the cortical frontal lobe. These effects might be attributed to the impact of the gut microbiota on the enzymes affecting availability of tryptophan and serotonin pathway and the amino acid utilization by the bacteria [61]; however, the exact mechanisms and the role of different factors including gender, and strains of mice have not been elucidated yet.

Moreover, the presence of serotonin receptors on immune cells including monocytes, macrophages, lymphocytes, and dendritic cells, may shed light on the impact of this neurotransmitter on immune modulation. This issue might also explain effects of serotonin on inflammatory 
state of the intestine and its role in increasing the susceptibility for GI diseases (such as Crohn's disease, ulcerative colitis, celiac disease and diverticulitis) [61].

\section{Migraine and gastrointestinal disorders}

To date, several researches have shown that migraine is associated with some GI disturbances such as diarrhea, constipation [62, 63], dyspepsia [64], and gastroesophageal reflux (GERD) [65]. Additionally, some GI disorders including HP infection [66, 67], IBS [68, 69], CD [70], and IBD [71-73] have also been associated with migraine.

\section{Helicobacter pylori infection}

Based on the findings of a meta-analysis of 5 casecontrol studies, about $45 \%$ of migraineurs harbor HP, while the prevalence rate among healthy controls was estimated at about 33\% [66]. It is noteworthy that when aiming at investigating the role of HP infection in headache pathogenesis, various strains of the bacterium, ethnicity of the studied patients, the variation of HP in different regions, and the potential pathological differences which would be present in different subtypes of headache, should be considered [18].

According to a review article findings, evidence supported that HP eradication may be associated with relief of migraine symptoms [67]. Also, Faraji et al. 2012 [74] compared the effects of HP eradication treatment with placebo among patients who received migraine treatment within a randomized, double-blind, controlled trial. They reported that at the end of study, patients who received HP eradication treatment showed lower migraine-related disability level compared with those in placebo group [74].

HP infection is supposed to be related to a persistent chronic inflammatory state, which in turn may lead to increased production of inflammatory mediators and vasoactive compounds $[18,75]$. Therefore, the proposed mechanism for the association between migraine and HP infection may include induced immune, inflammatory, and vascular responses and subsequent release of immune cells, inflammatory and vasoactive agents into the gastric mucosa that may finally lead to hypersensitivity of brain pain-sensitive structures [66]. Moreover, the neuroendocrine release of other factors involved in migraine pathophysiology including serotonin, SP, and VIP appeared to be altered by the inflammatory state caused by the bacterium [66]. Particularly, it has been demonstrated that the levels of CGRP were elevated in HPinduced duodenal ulcers when comparing to healthy individuals $[18,44,76]$. Furthermore, higher IL-10 plasma levels have been observed during migraine attacks [77]; on the other hand, some studies showed that HP infection is associated with increased levels of IL-12 and IL-10 [78-80]. These observations may suggest that
IL-10 stimulated by HP may exacerbate the severity of migraine.

Collectively available data indicate that HP may impact on migraine symptoms. However, at the moment this is still a matter of research and there is no evidence to support systematic search of the infection in migraineurs nor the treatment of the infection specifically aimed to improve migraine symptoms.

\section{Irritable bowel syndrome}

IBS and migraine share some similarities, i.e. both disorders are chronic, recurrent [69], and more prevalent among women, have high individual/social burden, highly affect the patients' quality of life, and seem to be accompanied by a number of comorbid psychological diseases especially anxiety [69, 81-85]. Furthermore, central, visceral and thermal cutaneous hypersensitization are common among both disorders [69]. Overall, $60 \%$ of migraineurs have allodynia and IBS patients reported to have allodynia aside from visceral hypersensitivity [69]. N-methyl-D-aspartate (NMDA) may probably be responsible for allodynia among the IBS patients [86].

There is an established association between migraine and IBS, such that IBS was revealed to be common among migraineurs and migraine was reported to be prevalent among IBS suffers [18]. A prevalence cohort study showed that in comparison to non-IBS subjects, IBS patients had a $40-80 \%$ higher prevalence odds of migraine, depression, and fibromyalgia [68]. A further study, found that about $17 \%$ of IBS patients had migraine while only $8 \%$ of the control group suffered from this type of headache [87]. A meta-analysis on 6 studies showed that individuals who suffered from IBS had coexisting headache with an estimated OR of approximately 2.7 [69]. On the other hand, higher prevalence of IBS in migraineurs has been also reported with a rate ranging from $4 \%$ to $40 \%$ [69, 81-85]. Migraineurs with long headache history and high headache frequency had a higher chance of being diagnosed with IBS [88].

Mechanisms underlying the association are not entirely clear. Similar to migraine, IBS can alter gut microflora composition and thereby may affect the gut-brain axis and inflammatory status [13, 89-93]. Moreover, food allergies/intolerances that seem to cause migraine attack initiation and relapse of IBS may also explain the association between the disorders [92]. With respect to this, food elimination diets based on IgG antibodies may effectively reduce symptoms in migraine patients with concomitant IBS [94]. Hereditary and genetic polymorphism might explain at least in part the comorbidity between migraine and IBS [69].

Also $5 \mathrm{H}-\mathrm{T}$ has been postulated to play a role in the association of migraine and IBS. Serotonin release from entrochromaffin cells in the gastric pits of the stomach 
luminal epithelium stimulates gastric acid secretion, sensory and motor GI reflexes which in turn activates the ENS $[69,95,96]$. Interestingly, it was observed that patients with IBS had higher systemic levels of serotonin and kynurenic acid when compared to healthy individuals, which implies that serotonin function in these patients might be impaired as a result of augmented kynurenic pathway activation [18, 61]. Therapeutic agents modulating serotonin receptors are effective in patients with both disorders (i.e. IBS and migraine) [97]. Sexual hormones are also believed to play a role, because migraine and IBS are more prevalent among females. In addition, estrogen enhances serotonin release in the brain and increases pain sensitivity [98].

\section{Celiac disease}

$\mathrm{CD}$ is an autoimmune multisystem condition caused by gluten peptide in genetically susceptible individuals [99]. According to the available data, the prevalence of $C D$ is $1.4 \%$ [100]. A variety of neurologic manifestations have been observed with $\mathrm{CD}$ such as epilepsy, ataxia, cerebellar ataxia, mood disorders, encephalitis, peripheral neuropathy, neuromuscular disorders, dementia, learning disorders, developmental delay and migraine [101]. A "nutritional-microbial-epithelial-neuronal" akin to "environmental-luminal-mucosal-neuronal" brain network may be responsible for these extra-intestinal manifestations [102]. Studies have shown that patients with $C D$ have higher prevalence of migraine compared with healthy controls and vice versa $[103,104]$. It is estimated that about $21-28 \%$ of patients with CD have migraine [104-106]. Migraine-like headache may represent the initial feature of $\mathrm{CD}[103$, 107-109]. Some studies suggest that evidence of occipital and parieto-occipital calcifications and white matter abnormalities at brain neuroimaging are associated with comorbid CD in subjects with migraine [103, 110-112]. Clinicians may consider to search for $\mathrm{CD}$ in subjects with migraine in the presence of such alterations especially if other symptoms suggestive of $\mathrm{CD}$ are present. The association between migraine and $\mathrm{CD}$ may be attributed to several concurrent mechanisms including proinflammatory cytokines induced by gluten (e.g. IFN- and TNF- that are thought to enhance CGRP levels), lack of vitamins and macro elements due to malabsorption, vascular tone disturbances, nervous system hypersensitivity, brain hypoperfusion and perivascular inflammation [18, 103, 113-117]. It was also suggested that $\mathrm{CD}$ treatment may improve headache [118]. There are some studies which suggest that institution of gluten-free diet also may be effective in decrease of migraine frequencies $[18,103,119]$.

\section{Inflammatory bowel disease}

IBD is a chronic relapsing-remitting inflammatory condition that consists of Crohn disease and ulcerative colitis [120]. Data about possible relationship between headache or migraine and IBD are scarce [19]. A case-control study showed that the prevalence of headache was higher in IBD individuals compared to control group (46\% vs 7\%) [71]. In a Brazilian study, headache was the most common neurologic manifestation in IBD patients; $25 \%$ of patients with headache fulfilled the criteria for migraine [72]. A cross-sectional study performed in a tertiary-care headache center demonstrated that migraine prevalence was two-fold higher in IBD individuals compared to general population [73]. A further study reported a higher prevalence of migraine in patients with IBD (21.3\%) compared to non-IBD subjects (8.8\%) [121]. Although the exact mechanism remained unclear, but autoimmune-inflammatory responses, malabsorption, endothelial dysfunction that are present in IBD as well as immunosuppressive treatments prescribed for the disorder might be involved in pathophysiology underlying the association between IBD and migraine [121-123].

\section{Dietary approaches in migraine headache with a focus on the gut-brain Axis}

Different dietary approaches have been suggested for subjects with migraine [117], but at the moment it is unclear if any diet can be used to improve migraine management. It is important that those studies are very difficult to put into context because difficulties in maintaining the dietary strategy, in establishing adherence to the regimen, and in blindness in the study design. Overall, there is lack of high quality, well-designed clinical trials in this field, and available data are preliminary and should be interpreted with caution.

\section{Probiotic supplementation}

Probiotic supplementation may modulate migraine attacks. Possible mechanisms of action are unclear and include promoting SCFA production in the gut and improving epithelial integrity of the intestine and enhancing inflammation by nuclear factor kappa-B (NF-kB) pathway suppression and therefore lowering proinflammatory cytokines levels [37, 89, 90, 124-127]. Probiotics could also enhance the gastric emptying rate and attenuate gastric stasis - a common GI complaint among migraineurs - by neuroimmune interaction [91, 128, 129].

Some studies have explored the beneficial effects of probiotic administration on migraine headaches [89, $126,127,130]$. In a randomized double-blind controlled trial, the effect of daily adminstration of a 14-strainprobiotic mixture or placebo for 8 weeks in chronic and 10 weeks in episodic migraineurs was evaluated. Probiotic administration resulted in significant improvements in frequency and severity of migraine and the consumption of abortive medications in the studied population despite no significant changes in serum levels of selected inflammatory biomarkers [127]. 
In an open-label trial in 40 migraineurs, 12-week supplementation with probiotic + minerals + vitamins + herbs, resulted in significant improvement in patients quality of life in approximately $80 \%$ of the subjects and pain relief in more than half of the migraineurs [126]. In a further study, supplementation with a probiotic mixture of 7 bacterial strains reduced the migraine attacks frequency by about a quarter and also lowered migrainerelated disability [89]. However, a more recent study by the same group of authors reported conflicting results and found no changes in migraine-related outcomes with the same treatment [93]. The studied that were performed on effects of probiotic supplementation on migraine headache are summarized in Table 1.

\section{Carbohydrate}

Gut microbiota fermented resistance carbohydrate to different metabolites, such as SCFAs [131]. The dietary shift to high resistance polysaccharides increases SCFAs levels [28]. In a randomized clinical study, 350 migraineurs were allocated to low glycemic index diet (considered as a highfiber intake) group or to prophylactic medications group (either propranolol, flunarazine, amitriptyline or topiramate) in a 1:1 ratio. One month after dietary restrictions, the frequency of attacks was significantly reduced in both the diet and the pharmacological group. The befit was maintained at 90-day. Severity of attacks was reduced at both 30 - and 90-day in the drug group but only at 90-day in the diet group [132].

\section{Fat}

Chronic exposure to omega-3 in utero and early life, increases the proliferation of Lactobacillus and Bifidobacterium and sp., results in more SCFAs production [133]. Four studies assessed the effect of low-fat diets in migraine prophylaxis. Reducing dietary fat intake for three months resulted in the reduction in headache intensity, frequency and abortive medicine consumption [53, 134-136]. In a 12-week trial adults with chronic migraine randomly assigned to have high omega-3/low omega- 6 diet or low omega- 6 diet. Individuals on high omega-3/low omega- 6 diet experienced higher improvement in their headache compared to migraineurs on low omega- 6 diet [134]. The observed effect was attributed to the followings [117]: [1] the balance between the two eicosanoid pathways, omega- 6 and omega- 3 , contribute to inflammation control [2]; omega-6 fatty acids promote vasodilation [3]; high-fat diet induces hypercoagulability [4]; dietary fat affects serotonin release from platelet. Although high-fat diet reduces the proliferation of the SCFAs producing bacteria, the effect of fat intake on gut microflora and SCFAs production in migraineurs was not addressed yet in the studies. Table 2 represents a summary of the studies were conducted on effects of low fat diet on migraine headache.

\section{Vitamins}

Vitamin D3 supplementation affected the intestinal microbiota composition. Supplementing healthy individuals with vitamin D3 for 8 weeks also significantly reduced Helicobacter sp. count [137]. Several studies reported that serum levels of vitamin D might be associated with increased risk of migraine/headache [138, 139]. Further, it has been suggested that the prevalence of deficiency/insufficiency of this vitamin may be higher in patients who suffer from migraine/ headache when comparing to headache-free individuals [139]. Also favorable effects of

Table 1 Literatures on effects of probiotic supplementation on migraine headache

\begin{tabular}{|c|c|c|c|c|c|}
\hline authors and year & Type of article & Sample size & Type of probiotics & $\begin{array}{l}\text { Duration } \\
\text { of } \\
\text { treatment }\end{array}$ & Results \\
\hline $\begin{array}{l}\text { De Roos N, Giezenaar C, Rovers } \\
\text { J, et al. } 2015 \text { [89] }\end{array}$ & Clinical trial & 29 patients & $\begin{array}{l}2 \mathrm{~g} / \mathrm{d} \text { of a probiotic food } \\
\text { supplement }\left(\text { Ecologic }\left({ }^{\oplus}\right) \text { Barrier, }\right. \\
2.5 \times 10(9) \mathrm{cfu} / \mathrm{g})\end{array}$ & 12 weeks & $\begin{array}{l}\text { 1) number of migraine days/month } \\
\text { decreased significantly } \\
\text { 2) The MIDAS score improved } \\
\text { 3) Headache Disability Inventory } \\
\text { (HDI) did not change significantly }\end{array}$ \\
\hline $\begin{array}{l}\text { de Roos N, van Hemert S, } \\
\text { Rovers J, et al. } 2017 \text { [130] }\end{array}$ & $\begin{array}{l}\text { Randomized } \\
\text { control trial }\end{array}$ & $\begin{array}{l}63 \text { patients } \\
\text { (probiotic }(n=31) \\
\text { placebo group } \\
(n=32))\end{array}$ & $\begin{array}{l}\text { multispecies probiotic }\left(5 \times 10^{9}\right. \\
\text { colony-forming units }) \text { or } \\
\text { placebo daily }\end{array}$ & 12 weeks & $\begin{array}{l}\text { No significant benefit from a } \\
\text { multispecies probiotic compared } \\
\text { to a placebo on the outcome } \\
\text { parameters of migraine and } \\
\text { intestinal integrity }\end{array}$ \\
\hline $\begin{array}{l}\text { James Sensenig N, Jeffrey } \\
\text { Marrongelle D and CCN MJ S. T. } \\
2001[126]\end{array}$ & Clinical trial & 40 patients & $\begin{array}{l}\text { Two nutritional formulations } \\
\text { contained probiotics }+ \\
\text { minerals + vitamins }+ \text { herbs }\end{array}$ & 3 months & $\begin{array}{l}80 \% \text { of the participants experienced } \\
\text { significant improvements in quality } \\
\text { of life and pain relief in more than } \\
\text { half of the migraineurs }\end{array}$ \\
\hline $\begin{array}{l}\text { Martami F, Togha M, } \\
\text { Seifishahpar M, et al. } 2019 \text { [127] }\end{array}$ & $\begin{array}{l}\text { randomized } \\
\text { double-blind } \\
\text { controlled trial }\end{array}$ & $\begin{array}{l}40 \text { episodic and } \\
39 \text { chronic } \\
\text { migraine patients }\end{array}$ & $\begin{array}{l}\text { 14-strain probiotic mixture } \\
\text { or placebo }\end{array}$ & 10 weeks & $\begin{array}{l}\text { Significant reduction in migraine } \\
\text { attacks, migraine severity, and the } \\
\text { number of abortive drugs in the } \\
\text { probiotic group compare to the } \\
\text { placebo group }\end{array}$ \\
\hline
\end{tabular}


Table 2 Literatures on effects of low fat diet on migraine headache

\begin{tabular}{|c|c|c|c|c|c|}
\hline Authors and year & $\begin{array}{l}\text { Type of } \\
\text { article }\end{array}$ & Sample size & Type of diet & $\begin{array}{l}\text { Duration of } \\
\text { treatment }\end{array}$ & Results \\
\hline $\begin{array}{l}\text { Ferrara LA, Pacioni D, Di Fronzo } \\
\text { V, Russo BF, Speranza E, Carlino } \\
\text { V, et al. } 2015 \text { [53] }\end{array}$ & $\begin{array}{l}\text { Crossover } \\
\text { intervention } \\
\text { trial }\end{array}$ & $\begin{array}{l}83 \text { episodic or chronic } \\
\text { migraineurs ( } 63 \text { female } \\
\text { and } 20 \text { male) }\end{array}$ & $\begin{array}{l}\text { a low-lipid and a normal-lipid } \\
\text { diet }\end{array}$ & $\begin{array}{l}3 \text { months }+3 \\
\text { months }\end{array}$ & $\begin{array}{l}\text { Significant reduction in } \\
\text { severity and number of } \\
\text { migraine attacks }\end{array}$ \\
\hline $\begin{array}{l}\text { Ramsden CE, Zamora D, Faurot } \\
\text { KR, et al. } 2013\end{array}$ & $\begin{array}{l}\text { randomized } \\
\text { trial }\end{array}$ & $\begin{array}{l}67 \text { patients with } \\
\text { chronic daily } \\
\text { headache } \\
(\mathrm{H} 3-\mathrm{L} 6=33, \mathrm{~L} 6=34)\end{array}$ & $\begin{array}{l}\text { High omega-3 + low omega-6 } \\
\text { fatty acid (H3-L6) or low } \\
\text { omega-6 fatty acid (L6) }\end{array}$ & 12 weeks & $\begin{array}{l}\text { Significant reduction in } \\
\text { HIT score, headaches day } \\
\text { per month, and headache } \\
\text { hours per day in H3-L6 } \\
\text { group }\end{array}$ \\
\hline $\begin{array}{l}\text { Bic Z, Blix GG, Hopp HP, Leslie } \\
\text { FM, Schell MJ. } 1999 \text { [135] }\end{array}$ & Clinical trial & 54 migraineurs & $\begin{array}{l}\text { limit fat intake to no more } \\
\text { than } 20 \mathrm{~g} / \text { day }\end{array}$ & 12 weeks & $\begin{array}{l}\text { Significant decrease in } \\
\text { headache frequency, } \\
\text { intensity, and duration } \\
\text { and medication intake }\end{array}$ \\
\hline $\begin{array}{l}\text { Bunner AE, Agarwal U, Gonzales } \\
\text { JF, Valente F, Barnard ND. } 2014\end{array}$ & $\begin{array}{l}\text { Crossover } \\
\text { trial }\end{array}$ & 42 migraineurs & $\begin{array}{l}\text { dietary instruction (a low-fat } \\
\text { vegan diet) and placebo } \\
\text { supplement }\end{array}$ & $\begin{array}{l}36 \text { weeks ( } 16 \\
\text { weeks }+4 \\
\text { weeks washout+ } \\
16 \text { weeks) }\end{array}$ & $\begin{array}{l}\text { Significant reduction in } \\
\text { headache severity and } \\
\text { frequency during the } \\
\text { diet period }\end{array}$ \\
\hline
\end{tabular}

vitamin D supplementation on intensity and frequency of migraine attacks have been reported [139].

\section{Weight loss approaches in migraine/headache}

Animal studies showed that obesity reduced gut permeability, reduced expression of tight junctions and could influence intestinal microbiota composition [140]. Pieces of evidence showed that obesity could increase the risk of episodic and chronic migraine [54, 141] while weight reduction can decrease the intensity, frequency, and duration of migraine headache in adults [142-144] and adolescents [145]. The link between obesity and headache was proposed to be attributed to shared pathophysiological features. Evidence showed an increase in CGRP plasma level of adult with obesity which is also pointed out in patients with migraine [146]. Furthermore, a rise in proinflammatory cytokines, such as IL-6 and TNFwas reported in obese individuals and at the acute headache onset [147]. A summary of the studies on effects of weight loss on migraine headache is shown in Table 3.

\section{Conclusion}

The current evidence shows that the gut-brain axis may impact on migraine despite the mechanism explaining this interaction is not entirely clear. Generally, this interaction seems to be influenced by multiple factors such as inflammatory mediators (IL-1 $\beta$, IL-6, IL-8, and TNF$\alpha$ ), gut microbiota profile, neuropeptides and serotonin pathway, stress hormones and nutritional substances. Neuropeptides including CGRP, SP, VIP, NPY are thought to have antimicrobial impact on a variety of the gut bacterial strains and thus speculated to be involved in the bidirectional relationship between the gut and the brain. Additionally, there is comorbidity between migraine and a number of conditions including HP infection, IBS, IBD, and CD. According to the current knowledge, migraine headache in patients harboring $\mathrm{HP}$ might be improved following the bacteria eradication. Migraineurs with long headache history and high headache frequency have a higher chance of being diagnosed with IBS. IBS and migraine share some similarities and

Table 3 Literatures on effects of weight loss on migraine headache

\begin{tabular}{|c|c|c|c|c|c|}
\hline authors and year & $\begin{array}{l}\text { Type of } \\
\text { article }\end{array}$ & Sample size & Type of intervention & $\begin{array}{l}\text { Duration } \\
\text { of } \\
\text { treatment }\end{array}$ & Results \\
\hline $\begin{array}{l}\text { Bond DS, Vithiananthan S, Nash JM, } \\
\text { Thomas JG, Wing RR. } 2011 \text { [142] }\end{array}$ & $\begin{array}{l}\text { Prospected } \\
\text { observational } \\
\text { study }\end{array}$ & 24 migraineurs & Bariatric surgery & 6 months & $\begin{array}{l}\text { Significant reduction in } \\
\text { headache severity, and } \\
\text { headache-related disability }\end{array}$ \\
\hline $\begin{array}{l}\text { Novack V, Fuchs L, Lantsberg L, } \\
\text { Kama S, Lahoud U, Horev A, } \\
\text { et al. } 2011 \text { [143] }\end{array}$ & $\begin{array}{l}\text { Prospective } \\
\text { study }\end{array}$ & $\begin{array}{l}29 \text { premenopausal } \\
\text { obese women with } \\
\text { diagnosis of migraine }\end{array}$ & Bariatric surgery & 6 months & $\begin{array}{l}\text { Significant reduction in } \\
\text { frequency of migraine attacks, } \\
\text { duration of the attacks, and } \\
\text { medication use during the } \\
\text { attack and improvement of } \\
\text { headache-related disability } \\
\text { post bariatric surgery }\end{array}$ \\
\hline $\begin{array}{l}\text { Verrotti A, Agostinelli S, D'Egidio C, } \\
\text { Di Fonzo A, Carotenuto M, Parisi P, } \\
\text { et al. } 2013 \text { [145] }\end{array}$ & Clinical trial & $\begin{array}{l}135 \text { obese } \\
\text { adolescent } \\
\text { migraineurs }\end{array}$ & $\begin{array}{l}\text { dietary education, specific } \\
\text { physical training, and } \\
\text { behavioral treatment }\end{array}$ & $\begin{array}{l}12 \\
\text { months }\end{array}$ & $\begin{array}{l}\text { Significant decrease in headache } \\
\text { frequency and intensity, use of } \\
\text { acute medications, and disability }\end{array}$ \\
\hline
\end{tabular}


can alter gut microflora composition and thereby may affect the gut-brain axis and inflammatory status. Migraine has been also associated with $\mathrm{CD}$ and the condition should be searched particularly in patients with migraine with occipital and parieto-occipital calcification at brain neuroimaging. In those patients, gluten-free diet can also be effective in reducing migraine frequency. Diet strategies may impact on migraine course and could represent a valuable instrument to improve migraine management. However, no definite conclusion can be drawn because of the limited evidence on migraine management with diet. It can be hypothesized that prescribing dietary approaches with beneficial effects on gut microbiota and gut-brain axis including appropriate consumption of fiber per day, adhering to a low glycemic index diet, supplementation with vitamin D, omega-3 and probiotics as well as weight loss dietary plans (in case of obese patients) could lead to improvements in migraine associated features.

\section{Abbreviations \\ 5-HIAA: 5-hydroxyindoleacetic acid; BDNF: brain-derived neurotrophic factor; CCK: cholecystokinin; CD: celiac disease; CGRP: Calcitonin-Gene-Related- Peptide; CM: chronic migraine; CNS: central nervous system; CRH: corticotrophin-releasing hormone; CSD: cortical spreading depression; EM: episodic migraine; ENS: enteric nervous system; GBD: Global Burden of Disease; GDNF: glial-derived neurotrophic factor; HP: Helicobacter pylori; HPA axis: The hypothalamic pituitary adrenal axis; IBD: Irritable Bowel Syndrome; IBS: Irritable Bowel Syndrome; ICHD-3: International Classification of Headache Disorders 3; IFN- : interferon gamma; IL: interleukin; LPS: lipopolysaccharides; MDA: malondialdehyde; NF-KB: nuclear factor kappa-B; NMDA: N-methyl-D-aspartate; NO: nitric oxide; NPY: Neuropeptide Y; NSAIDs: nonsteroidal anti-inflammatory drug; PAG: periaquiductal gray matter; PUFA: Polyunsaturated fatty acid; ROS: Reactive Oxygen Sepsis; SCFAs: short-chain fatty acids; SP: substance P; TNF-a: tumor necrosis factor- a; VAS: visual analogue scale; VIP: vasoactive intestinal peptide}

\section{Acknowledgements}

Authors would like to thank Dr. Samaneh Haghighi the scientific secretary of the 6th EHF-SAS and Ms. Francesca Romana Britti for helping in coordination of the 6th EHF-SAS in Iran.

\section{Authors' contributions}

All authors contributed equally. MA, SRJ, ZGh, FV and AGh are junior fellows, while, SS and MT are senior fellows of EHF-SAS. All authors contributed with data interpretation, drafting, revision of the manuscript and approved the final manuscript.

\section{Funding}

Not applicable.

\section{Availability of data and materials}

All included references in the present review article are available on the Internet.

\section{Ethics approval and consent to participate}

Not applicable.

\section{Consent for publication}

Not applicable.

\section{Competing interests}

There is no conflict of interest.

\section{Author details}

'Headache Department, Iranian Center of Neurological Research, Neuroscience Institute, Tehran University of Medical Sciences, Tehran, Iran. ${ }^{2}$ Department of Clinical Nutrition and Dietetics, Faculty of Nutrition and Food Technology, Shahid Beheshti University of Medical Sciences, Tehran, Iran. ${ }^{3}$ Cardiovascular Diseases Research Center, Department of Cardiology, Heshmat Hospital, School of Medicine, Guilan University of Medical Sciences, Rasht, Iran. ${ }^{4}$ Headache Department, Neurology Ward, Sina University Hospital, School of Medicine, Tehran University of Medical Sciences, Tehran, Iran. ${ }^{5}$ Department of Clinical and Molecular Medicine, Sapienza University of Rome, Rome, Italy. ${ }^{6}$ Department of Virology, Pasteur Institute of Iran, Tehran, Iran. ${ }^{7}$ Neuroscience section - Department of Applied Clinical Sciences and Biotechnology, University of L'Aquila, L'Aquila, Italy.

Received: 12 October 2019 Accepted: 23 January 2020

Published online: 13 February 2020

\section{References}

1. Stovner LJ, Nichols E, Steiner TJ, Abd-Allah F, Abdelalim A, Al-Raddadi RM et al (2018) Global, regional, and national burden of migraine and tensiontype headache, 1990-2016: a systematic analysis for the global burden of disease study 2016. The Lancet Neurology 17(11):954-976

2. Steiner TJ, Stovner LJ, Vos T (2016) GBD 2015: migraine is the third cause of disability in under 50s. J Headache Pain. 17(1):104

3. Steiner TJ, Stovner LJ, Vos T, Jensen R, Katsarava Z (2018) Migraine is first cause of disability in under 50s: will health politicians now take notice? J Headache Pain 19(1):17

4. Dodick DW (2018) A phase-by-phase review of migraine pathophysiology. Headache. 58(Suppl 1):4-16

5. Mayer EA, Tillisch K, Gupta A (2015) Gut/brain axis and the microbiota. J Clin Invest 125(3):926-938

6. Hindiyeh N, Aurora SK (2015) What the gut can teach us about migraine. Curr Pain Headache Rep 19(7):33

7. Asano Y, Hiramoto T, Nishino R, Aiba Y, Kimura T, Yoshihara K et al (2012) Critical role of gut microbiota in the production of biologically active, free catecholamines in the gut lumen of mice. Am J Physiol Gastrointest Liver Physiol 303(11):G1288-G1295

8. Barrett E, Ross RP, O'Toole PW, Fitzgerald GF, Stanton C (2012) GammaAminobutyric acid production by culturable bacteria from the human intestine. J Appl Microbiol 113(2):411-417

9. Cavaillon JM. Pro- versus anti-inflammatory cytokines: myth or reality. Cellular and molecular biology (Noisy-le-Grand, France). 2001;47(4):695-702

10. Murphy SF, Schaeffer AJ, Thumbikat $P$ (2014) Immune mediators of chronic pelvic pain syndrome. Nature reviews Urology 11(5):259-269

11. Theoharides TC, Donelan J, Kandere-Grzybowska K, Konstantinidou A (2005) The role of mast cells in migraine pathophysiology. Brain Res Brain Res Rev 49(1):65-76

12. Ramachandran $R$ (2018) Neurogenic inflammation and its role in migraine. Semin Immunopathol 40(3):301-314

13. O'Mahony SM, Clarke G, Borre YE, Dinan TG, Cryan JF (2015) Serotonin, tryptophan metabolism and the brain-gut-microbiome axis. Behav Brain Res 277:32-48

14. Amaral FA, Sachs D, Costa W, Fagundes CT, Cisalpino D, Cunha TM et al (2008) Commensal microbiota is fundamental for the development of inflammatory pain. Proc Natl Acad Sci U S A 105(6):2193-2197

15. Holzer P, Farzi A. Neuropeptides and the microbiota-gut-brain axis. Microbial endocrinology: The microbiota-gut-brain axis in health and disease: Springer; 2014. p. 195-219

16. Maqsood R, Stone TW (2016) The gut-brain Axis, BDNF. NMDA and CNS Disorders Neurochem Res 41(11):2819-2835

17. Wang HX, Wang YP (2016) Gut microbiota-brain Axis. Chin Med J 129(19): 2373-2380

18. Camara-Lemarroy CR, Rodriguez-Gutierrez R, Monreal-Robles R, Marfil-Rivera A (2016) Gastrointestinal disorders associated with migraine: $a$ comprehensive review. World J Gastroenterol 22(36):8149-8160

19. van Hemert S, Breedveld AC, Rovers JM, Vermeiden JP, Witteman BJ, Smits MG et al (2014) Migraine associated with gastrointestinal disorders: review of the literature and clinical implications. Front Neurol 5:241

20. Galland $L$ (2014) The gut microbiome and the brain. J Med Food 17(12):1261-1272 
21. Farzi A, Frohlich EE, Holzer P (2018) Gut microbiota and the neuroendocrine system. Neurotherapeutics. 15(1):5-22

22. Petrella C, Giuli C, Agostini S, Bacquie V, Zinni M, Theodorou V et al (2014) Maternal exposure to low levels of corticosterone during lactation protects against experimental inflammatory colitis-induced damage in adult rat offspring. PLoS One 9(11):e113389

23. Amini-Khoei H, Haghani-Samani E, Beigi M, Soltani A, Mobini GR, BalaliDehkordi $S$ et al (2019) On the role of corticosterone in behavioral disorders, microbiota composition alteration and neuroimmune response in adult male mice subjected to maternal separation stress. Int Immunopharmacol 66:242-250

24. Verdú EF, Bercik P, Verma-Gandhu M, Huang XX, Blennerhassett $P$, Jackson $W$ et al (2006) Specific probiotic therapy attenuates antibiotic induced visceral hypersensitivity in mice. Gut. 55(2):182-190

25. Lenz HJ, Mortrud MT, Rivier JE, Brown MR (1985) Calcitonin gene related peptide inhibits basal, pentagastrin, histamine, and bethanecol stimulated gastric acid secretion. Gut. 26(6):550-555

26. Tache Y, Pappas T, Lauffenburger M, Goto Y, Walsh JH, Debas H (1984) Calcitonin gene-related peptide: potent peripheral inhibitor of gastric acid secretion in rats and dogs. Gastroenterology. 87(2):344-349

27. Li Y, Jiang YC, Owyang C (1998) Central CGRP inhibits pancreatic enzyme secretion by modulation of vagal parasympathetic outflow. Am J Phys 275(5):G957-G963

28. Sandhu KV, Sherwin E, Schellekens H, Stanton C, Dinan TG, Cryan JF (2017) Feeding the microbiota-gut-brain axis: diet, microbiome, and neuropsychiatry. Transl Res 179:223-244

29. Peng L, He Z, Chen W, Holzman IR, Lin J (2007) Effects of butyrate on intestinal barrier function in a Caco-2 cell monolayer model of intestinal barrier. Pediatr Res 61(1):37-41

30. Wang L, Christophersen CT, Sorich MJ, Gerber JP, Angley MT, Conlon MA (2012) Elevated fecal short chain fatty acid and ammonia concentrations in children with autism spectrum disorder. Dig Dis Sci 57(8):2096-2102

31. Park J, Floch MH (2007) Prebiotics, probiotics, and dietary Fiber in gastrointestinal disease. Gastroenterol Clin N Am 36(1):47-63

32. Noble EE, Hsu TM, Kanoski SE (2017) Gut to brain Dysbiosis: mechanisms linking Western diet consumption, the microbiome, and cognitive impairment. Front Behav Neurosci 11:9

33. Albenberg LG, Wu GD (2014) Diet and the intestinal microbiome: associations, functions, and implications for health and disease. Gastroenterology. 146(6):1564-1572

34. Li H, Li T, Beasley DE, Heděnec P, Xiao Z, Zhang S et al (2016) Diet diversity is associated with beta but not alpha diversity of pika gut microbiota. Front Microbiol 7:1169

35. Parnell JA, Reimer RA (2012) Prebiotic fiber modulation of the gut microbiota improves risk factors for obesity and the metabolic syndrome. Gut Microbes 3(1):29-34

36. Marchiando AM, Graham WV, Turner JR (2010) Epithelial barriers in homeostasis and disease. Annu Rev Pathol 5:119-144

37. Mennigen R, Bruewer M (2009) Effect of probiotics on intestinal barrier function. Ann N Y Acad Sci 1165(1):183-189

38. Yücel M, Kotan D, Çiftçi GG, Çiftçi I, Cikriklar H (2016) Serum levels of endocan, claudin-5 and cytokines in migraine. Eur Rev Med Pharmacol Sci 20(5):930-936

39. Leung L, Cahill CM (2010) TNF-alpha and neuropathic pain--a review. J Neuroinflammation 7(1):27

40. Bruno PP, Carpino F, Carpino G, Zicari A (2007) An overview on immune system and migraine. Eur Rev Med Pharmacol Sci 11(4):245-248

41. Perini F, D'Andrea G, Galloni E, Pignatelli F, Billo G, Alba S et al (2005) Plasma cytokine levels in migraineurs and controls. Headache. 45(7):926-931

42. Dominguez C, Vieites-Prado A, Perez-Mato M, Sobrino T, Rodriguez-Osorio X, Lopez A et al (2018) Role of adipocytokines in the pathophysiology of migraine: a cross-sectional study. Cephalalgia. 38(5):904-911

43. Martami F, Razeghi Jahromi S, Togha M, Ghorbani Z, Seifishahpar M, Saidpour A (2018) The serum level of inflammatory markers in chronic and episodic migraine: a case-control study. Neurol Sci 39(10):1741-1749

44. Pathophysiology of Headaches From Molecule to Man. Paolo Martelletti RJ, editor: Springer, Cham; 2015

45. Noseda R, Borsook D, Burstein R (2017) Neuropeptides and neurotransmitters that modulate Thalamo-cortical pathways relevant to migraine headache. Headache. 57(Suppl 2):97-111

46. Filpa V, Moro E, Protasoni M, Crema F, Frigo G, Giaroni C (2016) Role of glutamatergic neurotransmission in the enteric nervous system and braingut axis in health and disease. Neuropharmacology. 111:14-33
47. Holzer P, Reichmann F (2012) Farzi AJN. Neuropeptide Y, peptide YY and pancreatic polypeptide in the gut-brain axis 46(6):261-274

48. Fischer JA, Born W (1985) Novel peptides from the calcitonin gene: expression, receptors and biological function. Peptides. 6(Suppl 3):265-271

49. Raybould HE (2007) Mechanisms of CCK signaling from gut to brain. Curr Opin Pharmacol 7(6):570-574

50. Ballaz S (2017) The unappreciated roles of the cholecystokinin receptor CCK (1) in brain functioning. Rev Neurosci 28(6):573-585

51. Yao G, Han X, Hao T, Huang Q, Yu T (2015) Effects of rizatriptan on the expression of calcitonin gene-related peptide and cholecystokinin in the periaqueductal gray of a rat migraine model. Neurosci Lett 587:29-34

52. O'Connor TP, van der Kooy D (1988) Enrichment of a vasoactive neuropeptide (calcitonin gene related peptide) in the trigeminal sensory projection to the intracranial arteries. J Neurosci 8(7):2468-2476

53. Ferrara LA, Pacioni D, Di Fronzo V, Russo BF, Speranza E, Carlino V et al (2015) Low-lipid diet reduces frequency and severity of acute migraine attacks. Nutr Metab Cardiovasc Dis 25(4):370-375

54. Ornello R, Ripa P, Pistoia F, Degan D, Tiseo C, Carolei A et al (2015) Migraine and body mass index categories: a systematic review and meta-analysis of observational studies. J Headache Pain. 16(1):27

55. Liou AP, Lu X, Sei Y, Zhao X, Pechhold S, Carrero RJ et al (2011) The Gprotein-coupled receptor GPR40 directly mediates long-chain fatty acidinduced secretion of cholecystokinin. Gastroenterology. 140(3):903-912

56. Clarke G, Grenham S, Scully P, Fitzgerald P, Moloney RD, Shanahan F et al (2013) The microbiome-gut-brain axis during early life regulates the hippocampal serotonergic system in a sex-dependent manner. Mol Psychiatry 18(6):666-673

57. Saulnier DM, Ringel Y, Heyman MB, Foster JA, Bercik P, Shulman RJ et al (2013) The intestinal microbiome, probiotics and prebiotics in neurogastroenterology. Gut Microbes 4(1):17-27

58. Foster JA, Neufeld K-AM (2013) Gut-brain axis: how the microbiome influences anxiety and depression. Trends Neurosci 36(5):305-312

59. Ghorbani Z, Nazari S, Etesam F, Nourimajd S, Ahmadpanah M, Razeghi JS (2018) The effect of Synbiotic as an adjuvant therapy to fluoxetine in moderate depression: a randomized multicenter trial. Arch Neurosci 5(2):e60507

60. Wikoff WR, Anfora AT, Liu J, Schultz PG, Lesley SA, Peters EC et al (2009) Metabolomics analysis reveals large effects of gut microflora on mammalian blood metabolites. Proc Natl Acad Sci U S A 106(10):3698-3703

61. Mittal R, Debs LH, Patel AP, Nguyen D, Patel K, O'Connor G et al (2017) Neurotransmitters: the critical modulators regulating gut-brain Axis. J Cell Physiol 232(9):2359-2372

62. Aamodt AH, Stovner $\sqcup$, Hagen K, Zwart JA (2008) Comorbidity of headache and gastrointestinal complaints. The Head-HUNT Study Cephalalgia 28(2):144-151

63. Inaloo S, Dehghani SM, Hashemi SM, Heydari M, Heydari ST (2014) Comorbidity of headache and functional constipation in children: a crosssectional survey. Turk J Gastroenterol 25(5):508-511

64. Meucci G, Radaelli F, Prada A, Bortoli A, Crotta S, Cerrato C et al (2005) Increased prevalence of migraine in patients with uninvestigated dyspepsia referred for open-access upper gastrointestinal endoscopy. Endoscopy. 37(7):622-625

65. Peşkersoy C, Peker \$̧, Kaya A, Ünalp A, Gökay N (2016) Evaluation of the relationship between migraine disorder andoral comorbidities: multicenter randomized clinical trial. Turkish journal of medical sciences 46(3):712-718

66. Su J, Zhou XY, Zhang GX (2014) Association between helicobacter pylori infection and migraine: a meta-analysis. World J Gastroenterol 20(40):1496514972

67. Savi L, Ribaldone DG, Fagoonee S, Pellicano R (2013) Is helicobacter pylori the infectious trigger for headache?: a review. Infectious disorders drug targets 13(5):313-317

68. Cole JA, Rothman KJ, Cabral HJ, Zhang Y, Farraye FA (2006) Migraine, fibromyalgia, and depression among people with IBS: a prevalence study. BMC Gastroenterol 6(1):26

69. Chang FY, Lu CL (2013) Irritable bowel syndrome and migraine: bystanders or partners? Journal of neurogastroenterology and motility 19(3):301-311

70. Gabrielli M, Cremonini F, Fiore G, Addolorato G, Padalino C, Candelli M et al (2003) Association between migraine and celiac disease: results from a preliminary case-control and therapeutic study. Am J Gastroenterol 98(3): 625-629

71. Ben-Or O, Zelnik N, Shaoul R, Pacht A, Lerner A (2015) The neurologic profile of children and adolescents with inflammatory bowel disease. J Child Neurol 30(5):551-557 
72. Oliveira GR, Teles BC, Brasil EF, Souza MH, Furtado LE, de Castro-Costa CM et al (2008) Peripheral neuropathy and neurological disorders in an unselected Brazilian population-based cohort of IBD patients. Inflamm Bowel Dis 14(3):389-395

73. Moisset X, Bommelaer G, Boube M, Ouchchane L, Goutte M, Dapoigny M et al (2017) Migraine prevalence in inflammatory bowel disease patients: a tertiary-care Centre cross-sectional study. Eur J Pain 21(9):1550-1560

74. Faraji F, Zarinfar N, Zanjani AT, Morteza A (2012) The effect of helicobacter pylori eradication on migraine: a randomized, double blind, controlled trial. Pain physician 15(6):495-498

75. Waeber C, Moskowitz MA (2005) Migraine as an inflammatory disorder. Neurology. 64(10 suppl 2):S9-S15

76. Yang H, Zou Y, Zhang X. [Determination of serum calicotonin gene-related peptide in patients with duodenal ulcer infected with Helicobacter pylori]. Hunan yi ke da xue xue bao = Hunan yike daxue xuebao = Bulletin of Hunan Medical University. 1999;24(3):273-4

77. Munno I, Marinaro M, Bassi A, Cassiano MA, Causarano V, Centonze V (2001) Immunological aspects in migraine: increase of IL-10 plasma levels during attack. Headache. 41(8):764-767

78. Haeberle HA, Kubin M, Bamford KB, Garofalo R, Graham DY, El-Zaatari F et al (1997) Differential stimulation of interleukin-12 (IL-12) and IL-10 by live and killed helicobacter pylori in vitro and association of IL-12 production with gamma interferon-producing T cells in the human gastric mucosa. Infect Immun 65(10):4229-4235

79. Windle HJ, Ang YS, Athie-Morales V, McManus R, Kelleher D (2005) Human peripheral and gastric lymphocyte responses to helicobacter pylori NapA and AphC differ in infected and uninfected individuals. Gut. 54(1):25-32

80. Hida N, Shimoyama T Jr, Neville P, Dixon MF, Axon AT, Shimoyama T Sr et al (1999) Increased expression of IL-10 and IL-12 (p40) mRNA in helicobacter pylori infected gastric mucosa: relation to bacterial cag status and peptic ulceration. J Clin Pathol 52(9):658-664

81. Park JW, Cho YS, Lee SY, Kim ES, Cho H, Shin HE et al (2013) Concomitant functional gastrointestinal symptoms influence psychological status in Korean migraine patients. Gut and liver 7(6):668-674

82. Watson WC, Sullivan SN, Corke M, Rush D (1978) Globus and headache: common symptoms of the irritable bowel syndrome. Can Med Assoc J 118(4):387-388

83. Lankarani KB, Akbari M, Tabrizi R (2017) Association of Gastrointestinal Functional Disorders and Migraine Headache: a Population Base study. Middle East journal of digestive diseases. 9(3):139-145

84. Lau Cl, Lin CC, Chen WH, Wang HC, Kao CH (2014) Association between migraine and irritable bowel syndrome: a population-based retrospective cohort study. Eur J Neurol 21(9):1198-1204

85. Martami F, Ghorbani Z, Abolhasani M, Togha M, Meysamie A, Sharifi A et al (2018) Comorbidity of gastrointestinal disorders, migraine, and tension-type headache: a cross-sectional study in Iran. Neurol Sci 39(1):63-70

86. Zhou Q, Price DD, Callam CS, Woodruff MA, Verne GN (2011) Effects of the $\mathrm{N}$-methyl-D-aspartate receptor on temporal summation of second pain (wind-up) in irritable bowel syndrome. J Pain 12(2):297-303

87. Vandvik PO, Wilhelmsen I, Ihlebaek C, Farup PG (2004) Comorbidity of irritable bowel syndrome in general practice: a striking feature with clinical implications. Aliment Pharmacol Ther 20(10):1195-1203

88. Li C, Yu S, Li H, Zhou J, Liu J, Tang W et al (2017) Clinical features and risk factors for irritable bowel syndrome in migraine patients. Pak J Med Sci 33(3):720-725

89. De Roos N, Giezenaar C, Rovers J, Witteman B, Smits M, Van Hemert S (2015) The effects of the multispecies probiotic mixture ecologic ${ }^{\circledR}$ barrier on migraine: results of an open-label pilot study. Benef Microbes 6(5):641-646

90. van Hemert S, Breedveld AC, Rovers JM, Vermeiden JP, Witteman BJ, Smits MG et al (2014) Migraine associated with gastrointestinal disorders: review of the literature and clinical implications. Front Neurol 5

91. Aurora SK, Papapetropoulos S, Kori SH, Kedar A, Abell TL (2013) Gastric stasis in migraineurs: etiology, characteristics, and clinical and therapeutic implications. Cephalalgia. 33(6):408-415

92. Georgescu D, Reisz D, Gurban CV, Georgescu LA, lonita I, Ancusa OE et al (2018) Migraine in young females with irritable bowel syndrome: still a challenge. Neuropsychiatr Dis Treat 14:21-28

93. de Roos NM, van Hemert S, Rovers JMP, Smits MG, Witteman BJM (2017) The effects of a multispecies probiotic on migraine and markers of intestinal permeability-results of a randomized placebo-controlled study. Eur J Clin Nutr 71(12):1455-1462
94. Aydinlar El, Dikmen PY, Tiftikci A, Saruc M, Aksu M, Gunsoy HG et al (2013) lgG-based elimination diet in migraine plus irritable bowel syndrome. Headache. 53(3):514-525

95. Crowell MD (2004) Role of serotonin in the pathophysiology of the irritable bowel syndrome. Br J Pharmacol 141(8):1285-1293

96. Mulak A, Paradowski L (2005) Migraine and irritable bowel syndrome. Neurol Neurochir Pol 39(4 Suppl 1):S55-S60

97. Camilleri M (2010) Review article: new receptor targets for medical therapy in irritable bowel syndrome. Aliment Pharmacol Ther 31(1):35-46

98. Gupta S, McCarson KE, Welch KM, Berman NE (2011) Mechanisms of pain modulation by sex hormones in migraine. Headache. 51(6):905-922

99. Shannahan S, Leffler DA (2017) Diagnosis and updates in celiac disease. Gastrointest Endosc Clin N Am 27(1):79-92

100. Singh P, Arora A, Strand TA, Leffler DA, Catassi C, Green PH et al (2018) Global prevalence of celiac disease: systematic review and meta-analysis. Clin Gastroenterol Hepatol 16(6):823-836 e2

101. Rani U, Imdad A, Beg M (2015) Rare neurological manifestation of celiac disease. Case Rep Gastroenterol 9(2):200-205

102. Aaron L, Torsten M, Patricia W (2019) Autoimmunity in celiac disease: Extraintestinal manifestations. Autoimmun Rev 18(3):241-246

103. Zis $P$, Julian T, Hadjivassiliou M (2018) Headache associated with coeliac disease: a systematic review and meta-analysis. Nutrients. 10(10):1445

104. Dimitrova AK, Ungaro RC, Lebwohl B, Lewis SK, Tennyson CA, Green MW et al (2013) Prevalence of migraine in patients with celiac disease and inflammatory bowel disease. Headache. 53(2):344-355

105. Burk K, Farecki ML, Lamprecht G, Roth G, Decker P, Weller M et al (2009) Neurological symptoms in patients with biopsy proven celiac disease. Movement disorders : official journal of the Movement Disorder Society 24(16):2358-2362

106. Lionetti E, Francavilla R, Maiuri L, Ruggieri M, Spina M, Pavone P et al (2009) Headache in pediatric patients with celiac disease and its prevalence as a diagnostic clue. J Pediatr Gastroenterol Nutr 49(2):202-207

107. Diaconu G, Burlea M, Grigore I, Anton DT, Trandafir LM (2013) Celiac disease with neurologic manifestations in children. Rev Med Chir Soc Med Nat lasi 117(1):88-94

108. Battistella PA, Mattesi P, Casara GL, Carollo C, Condini A, Allegri F et al (1987) Bilateral cerebral occipital calcifications and migraine-like headache. Cephalalgia. 7(2):125-129

109. Kopishinskaya SV, Gustov AV (2015) Gluten migraine. Zh Nevrol Psikhiatr Im S S Korsakova 115(8):13-17

110. Currie S, Hadjivassiliou M, Clark MJ, Sanders DS, Wilkinson ID, Griffiths PD et al (2012) Should we be 'nervous' about coeliac disease? Brain abnormalities in patients with coeliac disease referred for neurological opinion. J Neurol Neurosurg Psychiatry 83(12):1216-1221

111. La Mantia L, Pollo B, Savoiardo M, Costa A, Eoli M, Allegranza A et al (1998) Meningo-cortical calcifying angiomatosis and celiac disease. Clin Neurol Neurosurg 100(3):209-215

112. D'Amico D, Rigamonti A, Spina L, Bianchi-Marzoli S, Vecchi M, Bussone G (2005) Migraine, celiac disease, and cerebral calcifications: a new case. Headache. 45(9):1263-1267

113. Mormile R (2014) Celiac disease and migraine: is there a common backstage? Int J Color Dis 29(12):1571

114. Cady RK, Farmer K, Dexter JK, Hall J (2012) The bowel and migraine: update on celiac disease and irritable bowel syndrome. Curr Pain Headache Rep 16(3):278-286

115. Nenna R, Petrarca L, Verdecchia P, Florio M, Pietropaoli N, Mastrogiorgio G et al (2016) Celiac disease in a large cohort of children and adolescents with recurrent headache: a retrospective study. Dig Liver Dis 48(5):495-498

116. Lionetto L, Negro A, Palmisani S, Gentile G, Del Fiore MR, Mercieri M et al (2012) Emerging treatment for chronic migraine and refractory chronic migraine. Expert Opin Emerg Drugs 17(3):393-406

117. Razeghi Jahromi S, Ghorbani Z, Martelletti P, Lampl C, Togha M (2019) Association of diet and headache. J Headache Pain. 20(1):106

118. Serratrice J, Disdier P, de Roux C, Christides C, Weiller PJ (1998) Migraine and coeliac disease. Headache. 38(8):627-628

119. Hadjivassiliou M, Grunewald RA, Lawden M, Davies-Jones GA, Powell T, Smith CM (2001) Headache and CNS white matter abnormalities associated with gluten sensitivity. Neurology. 56(3):385-388

120. Chang S, Shen B. Classification and Reclassification of Inflammatory Bowe Diseases: From Clinical Perspective. Interventional Inflammatory Bowel Disease: Endoscopic Management and Treatment of Complications: Elsevier; 2018. p. 17-34 
121. Chehel Cheraghi S, Ebrahimi Daryani N, Ghabaee M (2016) A survey on migraine prevalence in patients with inflammatory bowel disease - a single Centre experience. Middle East journal of digestive diseases 8(4):282-288

122. Doulberis M, Saleh C, Beyenburg S (2017) Is there an association between migraine and gastrointestinal disorders? Journal of Clinical Neurology 13(3):215-226

123. Fellermann K, Steffen M, Stein J, Raedler A, Hamling J, Ludwig D et al (2000) Mycophenolate mofetil: lack of efficacy in chronic active inflammatory bowel disease. Aliment Pharmacol Ther 14(2):171-176

124. Dai YJ, Wang HY, Wang XJ, Kaye AD, Sun YH (2017) Potential beneficial effects of probiotics on human migraine headache: a literature review. Pain physician. 20(2):E251-E2E5

125. Plaza-Diaz J, Ruiz-Ojeda FJ, Vilchez-Padial LM, Gil A. Evidence of the AntiInflammatory Effects of Probiotics and Synbiotics in Intestinal Chronic Diseases. Nutrients. 2017;9(6)

126. James Sensenig N, Jeffrey Marrongelle D, CCN MJS (2001) T. Treatment of migraine with targeted nutrition focused on improved assimilation and elimination. Altern Med Rev 6(5):488-494

127. Martami F, Togha M, Seifishahpar M, Ghorbani Z, Ansari H, Karimi T et al (2019) The effects of a multispecies probiotic supplement on inflammatory markers and episodic and chronic migraine characteristics: a randomized double-blind controlled trial. Cephalalgia. 39(7):841-853

128. Romeo MG, Romeo DM, Trovato L, Oliveri S, Palermo F, Cota F et al (2011) Role of probiotics in the prevention of the enteric colonization by Candida in preterm newborns: incidence of late-onset sepsis and neurological outcome. J Perinatol 31(1):63-69

129. Indrio F, Riezzo G, Raimondi F, Bisceglia M, Filannino A, Cavallo L et al (2011) Lactobacillus reuteri accelerates gastric emptying and improves regurgitation in infants. Eur J Clin Investig 41(4):417-422

130. de Roos N, van Hemert S, Rovers J, Smits M, Witteman B (2017) The effects of a multispecies probiotic on migraine and markers of intestinal permeabilityresults of a randomized placebo-controlled study. Eur J Clin Nutr

131. Collins SM (2014) A role for the gut microbiota in IBS. Nat Rev Gastroenterol Hepatol 11(8):497-505

132. Evcili G, Utku U, Ogun MN, Ozdemir G (2018) Early and long period follow-up results of low glycemic index diet for migraine prophylaxis. Agri. 30(1):8-11

133. Hildebrandt MA, Hoffmann C, Sherrill-Mix SA, Keilbaugh SA, Hamady M, Chen YY et al. High-fat diet determines the composition of the murine gut microbiome independently of obesity. Gastroenterology. 2009:137(5):1716-24 e1-2

134. Ramsden CE, Zamora D, Makriyannis A, Wood JT, Mann JD, Faurot KR et al (2015) Diet-induced changes in n-3-and n-6-derived endocannabinoids and reductions in headache pain and psychological distress. J Pain 16(8):707-716

135. Bic Z, Blix GG, Hopp HP, Leslie FM, Schell MJ (1999) The influence of a lowfat diet on incidence and severity of migraine headaches. J Womens Health Gend Based Med 8(5):623-630

136. Bunner AE, Agarwal U, Gonzales JF, Valente F, Barnard ND (2014) Nutrition intervention for migraine: a randomized crossover trial. J Headache Pain. 15(1):69

137. Bashir M, Prietl B, Tauschmann M, Mautner SI, Kump PK, Treiber G et al (2016) Effects of high doses of vitamin D3 on mucosa-associated gut microbiome vary between regions of the human gastrointestinal tract. Eur J Nutr 55(4):1479-1489

138. Togha M, Razeghi Jahromi S, Ghorbani Z, Martami F, Seifishahpar M (2018) Serum vitamin D status in a Group of Migraine Patients Compared with Healthy Controls: a case-control study. Headache. 58(10):1530-1540

139. Ghorbani Z, Togha M, Rafiee P, Ahmadi ZS, Rasekh Magham R, Haghighi S et al (2019) Vitamin D in migraine headache: a comprehensive review on literature. Neurol Sci 40(12):2459-2477

140. Nagpal R, Newman TM, Wang S, Jain S, Lovato JF, Yadav H (2018) Obesitylinked gut microbiome Dysbiosis associated with derangements in gut permeability and intestinal cellular homeostasis independent of diet. J Diabetes Res 2018:3462092

141. Gelaye B, Sacco S, Brown WJ, Nitchie HL, Ornello R, Peterlin BL (2017) Body composition status and the risk of migraine: a meta-analysis. Neurology. 88(19):1795-1804

142. Bond DS, Vithiananthan S, Nash JM, Thomas JG, Wing RR (2011) Improvement of migraine headaches in severely obese patients after bariatric surgery. Neurology. 76(13):1135-1138

143. Novack V, Fuchs L, Lantsberg L, Kama S, Lahoud U, Horev A et al (2011) Changes in headache frequency in premenopausal obese women with migraine after bariatric surgery: a case series. Cephalalgia. 31(13):1336-1342

144. Jahromi SR, Abolhasani M, Ghorbani Z, Sadre-Jahani S, Alizadeh Z, Talebpour M et al (2018) Bariatric surgery promising in migraine control: a controlled trial on weight loss and its effect on migraine headache. Obes Surg 28(1):87-96

145. Verrotti A, Agostinelli S, D'Egidio C, Di Fonzo A, Carotenuto M, Parisi P et al (2013) Impact of a weight loss program on migraine in obese adolescents. Eur J Neurol 20(2):394-397

146. Bond DS, Roth J, Nash JM, Wing RR (2011) Migraine and obesity: epidemiology, possible mechanisms and the potential role of weight loss treatment. Obes Rev 12(5):e362-e371

147. Laino D, Vitaliti G, Parisi P, Pavone P, Verrotti A, Lubrano R et al (2016) Headache, migraine and obesity: an overview on plausible links. J Biol Regul Homeost Agents 30(2):333-338

\section{Publisher's Note}

Springer Nature remains neutral with regard to jurisdictional claims in published maps and institutional affiliations.
Ready to submit your research? Choose BMC and benefit from:

- fast, convenient online submission

- thorough peer review by experienced researchers in your field

- rapid publication on acceptance

- support for research data, including large and complex data types

- gold Open Access which fosters wider collaboration and increased citations

- maximum visibility for your research: over $100 \mathrm{M}$ website views per year

At $\mathrm{BMC}$, research is always in progress.

Learn more biomedcentral.com/submissions 